\title{
EVALUASI SEBAGAI ACUAN TINDAKAN KEPERAWATAN YANG LEBIH TEPAT
}

\author{
Rizka Safitri Siregar/181101041 \\ rizkasafitri223@gmail.com
}

\begin{abstract}
ABSTRAK
Tahap evaluasi merupakan perbandingan yang sistematik dan terencana tentang kesehatan klien dengan tujuan yang telah ditetapkan, dilakukan berkesinambungan dengan melibatkan klien dan tenaga kesehatan lainnya. Evaluasi keperawatan mungukur keberhasilan dari rencana dan pelaksanaan tindakan keperawatan yang dilakukan dalam memenuhi kebutuhan klien. Tujuan Untuk melihat kemampuan klien dalam mecapai tujuan. Hal ini bisa dilaksanakan dengan mengadakan hubungan dengan klien berdasarkan respon klien terhadap tindakan keperawatan yang diberikan, sehingga perawat dapat mengambil keputusan. Metode yang digunaka adalah metode kualitatif dimana maksudnya dengan cara mengumpulkan sebanyak-banyaknya data untuk dianalisis. Yaitu dengan Literature review ini dengan menganalisis yang berfokus pada tujuan evaluasi dalam keperawatan. Adapun tinjauan literatur yang digunakan seperti buku teks, bukureferensi, jurnal, dan google scholar. Dengan kata kunci tujuan evaluasi, dokumentasi evaluasi, tahap evaluasi. Dan yang digunakan adalah 14 literatur yang diterbitkan 10 tahun terakhir.
\end{abstract}

Kata kunci : Tujuan Evaluasi, Tindakan keperawatan, Tahap Evaluasi.

\section{PENDAHULUAN}

Sebagai perawat yang professional harus selalu berfikir kritis dari setiap tahap kita harus selalu berfikir kritis karena untuk keberhasilan perawatan terutama dalam tahap evaluasi. Evaluasi adalah suatu usaha untuk mengukur dan memberi nilai secara obyektif pencapaian hasil-hasil yang telah direncanakn sebelumnya. Evaluasi dalam keperawatan merupakan kegiatan dalam menilai tindaka keperawatan yang telah ditentukan, untuk mengetahui pemenuhan kebutuhan klien secara optimal dan mengukur hasil dari proses keperawatan. Evaluasi dalam keperawatan adalah kegiatan dalam menilai tindakan keperawatan yang telah ditentukan, untuk mengetahui pemenuhan kebutuhan klien secara optimal dan mengukur hasil dari proses keperawatan. Evaluasi yaitu penilaian hasil dan proses. Penilaian hasil menentukan seberapa jauh keberhasilan yang dicapai sebagai keluaran dari tindakan. Penilaian peoses menentukan apakah ada kekeliruan dari setiap tahapan proses mulai dari pengkajian, diagnosa, perencanaan, tindakan, dan evaluasi itu sendiri. Evaluasi 
merupakan tahap akhir yang bertujuan untuk menilai apakah tindakan keperawatan yang telah dilakukan tercapai atau tidak untuk mengatasi suatu masalah. Pada tahap evaluasi, perawat dapat mengetahui seberapa jauh diagnosa keperawatan, rencana tindakan, dan pelaksanaan telah tercapai. Meskipun tahap evaluasi diletakkan pada akhir proses keperawatan tetapi tahap ini merupakan bagian integral pada setiap tahap proses keperawatan. Pengumpulan data perlu direvisi untuk menentukan kecukupan data yang telah dikumpulkan dan kesesuaian perilaku yang observasi. Diagnosis juga perlu dievaluasi dalam hal keakuratan dan kelengkapannya. Evaluasi juga diperlukan pada tahap intervensi untuk menentukan apakah tujuan intervensi tersebut dapat dicapai secara efektif.

\section{TUJUAN}

Untuk melihat kemampuan klien dalam mecapai tujuan. Hal ini bisa dilaksanakan dengan mengadakan hubungan dengan klien berdasarkan respon klien terhadap tindakan keperawatan yang diberikan, sehingga perawat dapat mengambil keputusan.

\section{METODE}

Metode yang digunakan adalah metode kualitatif dimana maksudnya dengan cara mengumpulkan sebanyak-banyaknya data untuk dianalisis. Yaitu dengan Literature review ini dengan menganalisis yang berfokus pada tujuan evaluasi dalam keperawatan. Adapun tinjauan literatur yang digunakan seperti buku teks, bukureferensi, jurnal, dan google

scholar. Dengan kata kunci tujuan evaluasi, dokumentasi evaluasi, tahap evaluasi. Dan yang digunakan adalah 14 literatur yang diterbitkan 10 tahun terakhir.

\section{HASIL/PEMBAHASAN}

Tahap evaluasi merupakan perbandingan yang sistematik dan terencana tentang kesehatan klien dengan tujuan yang telah ditetapkan, dilakukan berkesinambungan dengan melibatkan klien dan tenaga kesehatan lainnya. Evaluasi keperawatan mungukur keberhasilan dari rencana dan pelaksanaan tindakan keperawatan yang dilakukan dalam memenuhi kebutuhan klien. Evaluasi dalam keperawatan merupakan kegiatan dalam menilai tindakan keperawatan yang telah ditentukan, untuk mengetahui pemenuhan kebutuhan klien secara optimal dan mengukur hasil dari proses keperawatan. Penilaian keberhasilan adalah tahap 
yang menentukan apakah tujuan tercapai. Evaluasi selalu berkaitan dengan tujuan, apabila dalam penilaian ternyata tujuan tidak tercapai, maka perlu dicari penyebabnya. Hal tersebut dapat terjadi karena beberapa faktor : tujuan tidak realistis, tindakan keperawatan yang tidak tepat dan terdapat faktor lingkungan yang tidak dapat diatasi. Alasan pentingnya penilaian sebagai berikut : menghentikan tindakan atau kegiatan yang tidak berguna, untuk menambah ketepatgunaan tindakan keperawatan, sebagai bukti hasil dari tindakan perawatan dan untuk pengembangan dan penyempurnaan praktik keperawatan. Tipe pernyataan evaluasi menurut Setiadi (2012) sebagai berikut: Tipe pernyataan tahapan evaluasi dapat dilakukan secara formatif dan sumatif. Evaluasi formatif adalah evaluasi yang dilakukan selama proses asuhan keperawatan, sedangkan evaluasi sumatif adalah evaluasi akhir. a) Pernyataan evaluasi formatif. Hasil observasi dan analisa perawat terhadap respon pasien segera pada saat atau setelah dilakukan tindakan keperawatan dan ditulis pada catatan perawatan. b) Pernyataan evaluasi sumatif. Rekapitulasi dan kesimpulan dari observasi dan analisa status kesehatan sesuai waktu pada tujuan dan ditulis pada catatan perkembangan. Tujuannya menjamin asuhan keperawatan secara optimal, meningkatkan kualitas asuhan keperawatan, mengakhiri rencana tindakan keperawatan, menyatakan apakah tujuan keperawatan telah tercapai atau belum, meneruskan rencana tindakan keperawatan, memodifikasi rencana tindakan keperawatan dan dapat menentukan penyebab apabila tujuan asuhan keperawatan belum tercapai.

Manfaatnya untuk menentukan perkembangan kesehatan klien, untuk menilai efektifitas, efisiensi, dan produktifitas dari tindakan keperawatan yang telah diberikan, untuk menilai pelaksanaan asuhan keperawatan, mendapatkan umpan balik dan sebagai tanggung jawab dan tanggung gugat dalam pelaksanaan pelayanan keperawatan. Jenis Evaluasi: 1) Evaluasi struktur, evaluasi struktur difokuskan pada kelengkapan tata cara atau keadaan sekeliling tempat pelayanan keperawatan diberikan. Aspek lingkungan secara langsung atau tidak langsung mempengaruhi dalam pemberian pelayanan. Persediaan perlengkapan, fasilitas fisik, ratio perawat-klien, dukungan administrasi, pemeliharaan dan pengembangan kompetensi staf keperawatan dalam area yang diinginkan. 2) Evaluasi proses, evaluasi proses berfokus pada penampilan kerja perawat dan apakah perawat dalam 
memberikan pelayanan keperawatan merasa cocok, tanpa tekanan, dan sesuai wewenang. Area yang menjadi perhatian pada evaluasi proses mencakup jenis informasi yang didapat pada saat wawancara dan pemeriksaan fisik, validasi dari perumusan diagnosa keperawatan, dan kemampuan tehnikal perawat. 3) Evaluasi hasil, evaluasi hasil berfokus pada respons dan fungsi klien. Respons prilaku klien merupakan pengaruh dari intervensi keperawatan dan akan terlihat pada pencapaian tujuan dan kriteria hasil.

\section{KESIMPULAN}

Evaluasi adalah proses penilaian pencapaian tujuan serta pengkajian ulang rencana keperawatan. Tujuan evaluasi adalah untuk melihat kemampuan klien dalam mecapai tujuan. Proses evaluasi meliputi : Mengukur pencapaian tujuan klien, Membandingkan data yang terkumpul dengan tujuan dan pencapaian tujuan. Komponen evaluasi meliputi: Menentukan kriteria, standar, dan pertanyaan evaluasi, Mengumpulkan data mengenai keadaan klien terbaru, Menganalisa dan membandingkan data terhadap kriteria dan standar, Merangkum hasil dan membuat kesimpulan, Melaksanakan tindakan yang sesuai berdasarkan kesimpulan.

\section{REFERENSI}

Anggraini, D., Hakim, L., \& Imam, C. W. (2014). Evaluasi Pelaksanaan Sistem Identifikasi Pasien di Instalasi Rawat Inap Rumah Sakit. Jurnal Kedokteran Brawijaya, 28(1), 99-105.

Astuti, Y. D., Dewi, A., \& Arini, M. (2017). Evaluasi Implementasi Clinical Pathway Sectio Caesarea di RSUD Panembahan Senopati Bantul.

Busono, P. B. T. (2010). Evaluasi Penerapan Model Praktek Keperawatan Profesional di ruang Maranata I Rumah Sakit Mardi Rahayu Kudus (Doctoral dissertation, Universitas Diponegoro).

Hariyati, R. T. S., Afifah, E., \& Handiyani, H. (2008). Evaluasi model perencanaan pulang yang berbasis teknologi informasi. Makara kesehatan, 12(2), 53-58. 
Potter, A.P., \& Perry, G.A. (2010). Fundamental Keperawatan Buku 1 Edisi 7. Jakarta : Salemba Medika

Potter, A., \& Perry, A. (2017). Buku Ajar Fundamental Keperawatan: Konsep, Proses, dan Praktik (4th ed.). Jakarta: Buku Kedokteran EGC.

Rosdahl, C. B., \& Kowalski, M. T. (2014). Buku Ajar Keperawatan Dasar. Jakarta: EGC

Serri, H. (2010). Konsep dan Dokumentasi Proses Keperawatan. Jakarta: Trans Info Medika .

Siahaan, D. N. (2012). Kinerja Perawat Dalam Pemberian Asuhan Keperawatan Di Rumah Sakit Tk Ii Putri Hijau Medan. Jurnal Keperawatan Holistik, 1(2).

Simamora, R. H. (2008). Peran Manajer Dalam Pembinaan Etika Perawat Pelaksana Dalam Peningkatan Kualitas Pelayanan Asuhan Keperawatan. IKESMA, 4(2)

Simamora, R. (2009). Dokumentasi Proses Keperawatan.

Simamora, R. (2010). Komunikasi dalam keperawatan

Sumijatun. (2010). Konsep Dasar Menuju Keperawatan Profesional. Jakarta: Trans Info Medika

Widodo, W. N., Wungow, H., \& Hamel, R. S. (2016). Hubungan Peran Ketua Tim Dengan Kinerja Perawat Pelaksana Dalam Pendokumentasian Asuhan Keperawatan Di Irina F Rsup Prof Dr. RD Kandou Manado. Jurnal Keperawatan, 4(2).

Tarwoto, \& Wartonah. (2010). Kebutuhan Dasar Manusia dan Proses Keperawatan. Jakarta: Salemba Medika 